\title{
STIMULATING STUDENT MORAL ENGAGEMENT IN THE SERVICE OF CIVIC EDUCATION
}

\author{
David Gerber \\ The University at Buffalo (SUNY), Emeritus
}

In the 1980 s, sensing in the general undergraduate population at my university a growing disengagement from public life and cynicism about politics and government, I sought ways of engaging students morally in the discussion of political decisionmaking. As a historian teaching the survey of United States History, 1865-present, I emphasized students' command of content and illustrated explicitly how historians think, but I also sought to promote moral engagement, a state of caring to define oneself in relation to questions of right and wrong or truth and untruth. Moral engagement, by this definition, is caring about caring. I conducted an experiment in civic education, derived, as I shall explain, from my own concerns about conveying civic responsibility. It was to last into the new millennium and was documented with a questionnaire administered to students for sixteen semesters. ${ }^{1}$ I did not teach civics in the traditional sense, but rather invited students to be engaged in a common task of democratic citizenship: evaluating a decision of elected officials done in the name of the democratic electorate, and in a moral sense, though in the distant past, in their names, too.

This essay is a discussion of the methods and consequences of that experiment, from both my own perspective and that of the students, for whom the questionnaire served as a way of explaining what they had learned, both about President Harry Truman's decision to use the atomic bombs in 1945 and about themselves in thinking about, and perhaps rethinking, that decision. I believe the data collected from over 600 students over the course of almost two decades to be a unique record of student learning and moral engagement on one fateful issue. Moreover, that record suggests reasons for optimism about what we can accomplish in the limited context of a survey course by encouraging students to invest their minds in thinking through moral questions that lie at the heart of the exercise of democratic citizenship. The experience recorded may on one level certainly be read as a case study of an approach to teaching a controversial and significant issue regarding moral inquiry about war strategy and the uses of violence. But the agenda I want to advance most is one that goes beyond Hiroshima and Nagaski; I am interested in using the classroom to encourage students to believe it is their obligation to join the civic culture.

\footnotetext{
'The questionnaire stood apart from my department's formal course evaluation process, which was administered at the end of the semester. In this version of the essay, only a portion of the data derived from the questionnaire is presented. A longer version of the paper and a fuller presentation of the results of the questionnaire may be found at www.dagerber.com.
} 


\section{The Role of the Survey of United States History}

While the survey's existence is often justified as a means to dispense facts and information, to my mind, the defense of the survey is a defense of civic education. I believe the survey of United States History contributes to fulfilling a worthwhile goalproviding our students with moral foundations conducive to democratic citizenship.

The survey, whether at the high school or college and university levels, may well attempt to fulfill multiple goals as history along the lines of both the Five Cs (change, context, causality, contingency, and complexity) and with regard to its traditional purpose of providing a basic factual, content-driven narrative of the American past. ${ }^{2}$ Yet beyond those conventional pedagogical goals, for American students, a survey might also be conceived, as Wilfred McClay has observed from a Deweyan perspective, as a "rite of civic inclusion," necessary to civic education in a democratic polity. ${ }^{3}$ Students may be asked, in effect, to become engaged with the strivings of Americans in the past and, hence among other consequences of that engagement, to take imaginative responsibility at some level for the decisions, good and bad alike, of past generations and political leaders, such as the example of Truman as commander-inchief I will focus on in this essay. I would argue that before students can become engaged in learning about politics and government, let alone become effective citizens, they have to grow into the role by understanding that being a citizen is an obligation and is a part of what they should become to be effective and ethical people in their own time and place. They need to care enough to become informed, to have an opinion, and to assert their views on a matter of significance to the welfare of the community. At that level, McClay's "rite of civic inclusion" is an exercise in civic education, and its success or failure is more or less one key to the success or failure of the civic culture on which democracy depends.

At that level, too, the survey begins to transcend its narrow, if plausible, pedagogical goal as a dispenser of content, and to fulfill Ken Bain's standard for best instructional practices in the college and university classroom. In his study of successful instructors in higher education, Bain found that these instructors discovered ways of linking course material to larger issues to be faced in life, such as the responsible exercise of rights and of our obligations to the community in which we live, and of assisting students to develop habits of thought when facing meaningful issues that can be useful to them throughout their lives. If, in the process of facing "big

\footnotetext{
${ }^{2}$ Thomas Andrews and Flannery Burke, "What Does It Mean to Think Historically?," Perspectives on History 45 (January 2007).
}

${ }^{3}$ Wilfred McClay, "History, American Democracy, and the AP Test Controversy," Imprimis 44 (July/August 2015): 1-7. Still very much worth reading as a source of inspiration are John Dewey's The School and Society (Chicago: University of Chicago Press, 1900) and Democracy and Education (New York: Macmillan, 1916). 
questions" about the course of history, as it was shaped by big and small decisions alike of ordinary and elite Americans, students take in both content that we may regard as a mark of cultural literacy and a narrative of significant events, all the better. In fact, as studies of learning have repeatedly suggested, students are more likely to remember information when it is attached to a framework posing large questions and examining consequential issues than when it is memorized for the sake of getting a respectable grade on the final examination, the model for what Bain calls "bulimic education."

\section{My Formulation of the U.S. Survey}

I began teaching the second-half of the survey of U.S. History in the mid-1970s, and slowly, as I settled into making my section of the course my own, adopted strategies for engaging the students. In the years that I discuss in this essay I had an average enrollment of approximately 120 students per semester in the survey. The basic mode of instruction had to be lecturing, but I scheduled small-group discussion sections perhaps once a month and oriented toward discussion of a particular collateral reading beyond the textbook.

I soon came to understand that neither the students nor I could sustain interest in the course if it were only dedicated to dispensing information within a basic chronological narrative. Nor did I come to feel I could comfortably teach the 5 Cs. The occasional nod to disagreements among historians or the ambiguities of evidence aside, the survey is not the right time in the students' intellectual development or the right place in the curriculum to confront systematically serious philosophies, methodologies, and narrative construction, which require their own extended development to be appreciated. Many of the students in the course came from STEM and pre-vocational majors and would never have another history course. Teaching them something concrete about their country seemed more important than teaching something abstract about the construction of knowledge. Students took the survey to fulfill distribution requirements, and they regarded it as an imposition and distraction, a feeling that became especially pronounced when in the 1990s, it became a cognate for fulfilling a widely resented new university-wide requirement, broadly labeled American Pluralism, created in the name of teaching about diversity. Also, after the widespread political activism of the 1960s and early 1970s, campus activism and student interest in politics, government, and social issues faded, and students seemed centered increasingly on credentialing, undergraduate social rituals, and new consumer technologies.

My response was to seek to reengage them through two ways of presenting a post-1865 American narrative, both of which were departures from the more traditional

${ }^{4}$ Ken Bain, What the Best College Teachers Do (Cambridge: Harvard University Press, 2004), 8-9, 33, 35-38. 
presidential synthesis for organizing the survey narrative that I had experienced as an undergraduate. The first, which came as second nature to a practitioner of the New Social History of the 1970s, was to present the story of social change (Emancipation and Reconstruction, the decline of the family farm, industrialization, urbanization, economic depression, the liberalization of manners and morals, etc.) or of epic events, principally crucial elections $(1860,1896,1932,1968$, and 1980) and wars, through the experience of ordinary people and daily life. The majority of my lectures were organized around this essentially bottom-up (and middle-up) approach, which I believed had the potential to interest students, because it represented their own backgrounds. The second, out of which developed in the early 1980 s the unit on Truman's decision to use the atom bombs in 1945, was to step outside narrative and existential perspectives and examine in terms of moral reasoning momentous decisionmaking and its differing effects on differing groups of people. The point was to derive principles through which we could be comfortable with the conclusions we drew about the rightness or wrongness of decisions made in the past.

\section{Addressing the Use of the Atomic Bomb in the Classroom}

The choice of centering a unit of instruction around the morality of the use of the atomic bombs began with my own difficulties in lecturing about the subject in the first years I taught the survey. I had to make up my own mind what I believed about Truman's decision, a historical and a moral perennial that is destined to be thought and rethought, one hopes, for as long as there is a memory of World War II and there are anxieties about nuclear weapons. After some years of moving back and forth between approval and disapproval, I eventually reached the conclusion I would have made the same decision on the first bomb (at Hiroshima) that Truman, as commander-in-chief, had made in order to shorten the war, avoid invasion of the Japanese home islands, and save the lives of American troops under my command. But I also came to believe the second bomb (at Nagasaki) to have been morally indefensible and strategically unnecessary. Throughout the years I discussed this subject with them, I was candid with the students that it was a very difficult conclusion that I took a long time to reach, and that I continued to be uncomfortable with it. I invited the students both explicitly through my personal statement and implicitly through the effort to create an open forum for debate and disagreement, to share these difficulties, take possession of the issue, and be morally engaged with a decision made in the name of the American people, of which they are a part. ${ }^{5}$ This was my formal and explicit point of entry for involving students:

\footnotetext{
${ }^{5}$ I was not alone in seeing the value of this particular subject for morally engaging students in discussion, though I did not know it until long after I began to do research for this essay. In the mid-1980s, for example, Saul Bruckner, the principal of Brooklyn's Edward R. Murrow High School and himself a social studies teacher, shaped a discussion in an advanced placement U.S. History course around the
} 
I told them, in effect, that to be human, that is to say morally conscious beings and to be citizens of a democracy, they needed to care about decisions made in their name.

The instruction was characterized by a reading, a discussion section devoted entirely to the issue, a required short focus paper in which the students answered the question, "If you were Harry Truman what would you have done?," and, for the years 1983-2005, a short questionnaire administered at the end of the discussion section. The paper was intended not as a writing exercise, so much as a preparation for the discussion. I stopped lecturing on the decision, because I believed that would probably have overwhelmed the students with both my own way of reaching my conclusion and my conclusion itself. The lecture preceding the discussion dealt instead with American entrance into World War II after the attack on Pearl Harbor and American wartime strategy and diplomacy in both the Asian and European theaters of operations. I taught one of the discussion sections to which the students were assigned, and the other discussions - usually three to six for a total enrollment of between 100 and 200 students - were conducted by graduate assistants assigned to the course. Prior to the discussion sections, I typically met with the graduate teaching assistants to review the highlights of the lectures and readings and emphasize points of focus. In this unit, however, the instructions were different: After a brief review of the immediate wartime context of Truman's decision, they were to open a discussion to the question of what individual students would have done in Truman's position and the moral reasoning by which they came to that conclusion. Teaching assistants were to seek as broad participation as they could solicit, if necessary calling on individual students by name to give their opinions. I encouraged them to avoid giving the impression that there was a correct answer. They were to create an atmosphere suggesting a communal effort to arrive at a position with which, if not comfortable, we at least were not completely uncomfortable. And, as was the case with my own discussion section, I encouraged the teaching assistants to disclose their position in response to the question. We ought not to be construed by the students as exempt from the burden of the decision, as if somehow it was not our problem and only theirs.

In his survey of effective college and university teaching, Ken Bain found that instructors were often most effective when they took his approach to teaching complex material. Encouraging an open forum, open minds, and a communal approach to finding a path to truth and being frank about the difficulties making up one's own mind

\section{5....continued)}

question, "Was it moral for the United States to drop the atomic bomb on Japan?" Bruckner employed the same method of provocative, challenging questioning to stimulate a broad-based classroom discussion. See Diane Ravitch, The Schools We Deserve: Reflections on the Educational Crisis of Our Time (New York: Basic Books, 1985), 279-285. Bruckner's more direct question as far as the morality of the use of the atomic bomb is concerned was different from my own, which asked explicitly about American decision making, and which, by evoking the wartime context, made the exercise more complicated from the moral standpoint. I believe my formulation was probably more appropriate for university students. 
about an issue, Bain says, has proven effective in engaging students and assisting them to take control of issues placed before them and to retain what they are learning. ${ }^{6}$

Of course, it is an illusion that such a stance completely breaks down the difference in status and knowledge between instructors and students. The ways in which a discussion may appear to be intentionally and confidently directed within such a learning environment establishes the authority of the instructor. The teaching assistants and I did have questions we took to leading the discussions, and I encouraged the assistants to adopt the aggressively directed, Socratic-style of questioning that I employed in asking questions, soliciting answers, and moving about the room from student to student. Most of these questions were probably on the fringe of students' consciousness when they came to the discussion section, but we knew they needed to be explicitly addressed. Such questions were: Are there limits to how much violence is legitimate in a war context? Are civilian sites, such as private factories (even those involved in war production) or extensive urban settings with large numbers of civilian residents, legitimate targets? Should weapons that have never been previously deployed be used in a war when the consequences of using them are unknown? Are there limits to favoring the lives of troops under one's command over the lives of enemy forces? Is revenge morally justified as a basis for framing war tactics?

Instruction did not consist of providing authoritative answers to these questions. Instead it sought to introduce the questions as helpful ways to enable individual students to form their own conclusions and then balance a directed and focused discussion with as much classroom participation as possible. This model is urged on instructors by both those studying political socialization and those interested in how classroom practice may prepare students for participation in civic and political life beyond the classroom. The communal approach neither mandates nor is likely to eventuate in agreement, and this is one of its benefits. In learning to learn by such methods, Amy Guttman has observed, we develop not only the intellectual but also the emotional and affective capacities for citizenship, which requires virtues such as listening patiently and respectfully to others, while simultaneously evaluating what they have to say. ${ }^{7}$ It certainly is a method that can communicate, as Judith Torney-Purta notes in describing what is desirable in civics instruction, the need for a realistic viewpoint in thinking about democratic deliberation, in which of necessity conflict is

${ }^{6}$ Bain, What Do the Best College Teachers Do?, 28, 44.

${ }^{7}$ Amy Guttman, "Why Should Schools Care about Civic Education?," in Rediscovering the Democratic Purposes of Education, eds. Lorraine McDonnell, P. Michael Timpane, and Roger Benjamin (Lawrence: University of Kansas Press, 2002), 77-82; U.S. Department of Education, Advancing Civic Learning and Engagement in Democracy: A Road Map and Call to Action (Washington: DC: U.S. Department of Education, 2012), 8; Johnathan Gould, ed., Guardian of Democracy: The Civic Mission of the Schools (Philadelphia: Leonore Annenberg Institute for Civics, University of Pennsylvania, 2011), 6-20, 21 available at http://www.civicmissionofschools.org/the-campaign/guardian-of-democracy-report. 
likely, opinions may be passionately stated, and decision-making is likely to be messy. ${ }^{8}$ Probably for a related reason - encouraging passionate debate on questions that matter- "active learning" through interactions in the classroom seems to work best in civics instruction, just as it does in history classrooms. ${ }^{9}$

\section{Assigned Reading}

Much of the information brought into the discussion and guiding students' papers came from the assigned reading they were asked to do. Fortunately, I had confidence in the readings that I choose. I discuss these readings here in the context of the development of the historiography, and especially the conflicts among historians, on the decision to use the atomic bombs, though that was not the basis on which the books were presented to the students. The students were informed that the issue before them was not only why the bombs were used, the issue on which historians have disagreed, but rather should the bombs have been used. This guidance was provided by study questions distributed in class in advance of the assignment.

In the immediate postwar decades, the decision to use the atomic bombs was debated in memoirs and essays, largely to justify it or denounce it, on moral and strategic terms. No one questioned that the bomb was used to end the war, but rather whether it was needed to do so in light of the virtual collapse of Japan's ability to wage war. ${ }^{10}$ In 1965, as part of the emerging Left critique of American foreign and military policy during the Cold War, the literature took a decisive turn with the publication of Gar Alperovitz's revisionist Atomic Diplomacy. He argued that what was uppermost in the mind of Truman and his advisors was not Japan, which Alperovitz claimed they knew to be defeated and soon to surrender, but a desire to impress upon Josef Stalin, a member of the improbable allied coalition of American and British democratic capitalists and Soviet Communists, the necessity of cooperating with the United States in the reconstruction of the postwar world. Use of the atomic bombs, therefore,

\footnotetext{
${ }^{8}$ Judith Torney-Purta, "Review: Links and Missing Links between Education, Political Knowledge, and Citizenship," American Journal of Education 105 (August 1997): 450; Stephen E. Bennett, "Why Young Americans Hate Politics and What We Should Do About It," PS: Political Science and Politics 30 (March 1997): 52.
}

${ }_{9}^{9}$ Julia Smith and Richard Niemi, "Learning History in School: The Impact of Course Work and Instructional Practices on Achievement," Theory and Research in Social Education 29 (Winter 2001): 18-42; Torney-Purta, "Review: Links between Education, Political Knowledge, and Citizenship," 453 454 .

${ }^{10} \mathrm{On}$ the state of the historical literature about the use of the atomic bombs at the point in time when I was choosing the assigned readings, see J. Samuel Walker, "The Decision to Use the Bomb: A Historiographical Update," Diplomatic History 14 (January 1990): 97-114. 
appeared the last act of World War II, but was in reality, and consciously, the first act of the Cold War.

This work generated tremendous controversy, both for its attribution of blame for the Cold War and its contention that a weapon of mass destruction was unnecessarily used twice over large cities populated by civilians to make a political point irrelevant to the war against Japan. It then generated a post-revisionist literature that combined traditional arguments about ending the war with awareness that Truman and his advisors might also, as Alperovitz suggested, have seen the atomic bomb as a powerful tool in the effort to reshape the postwar world. Among the post-revisionist works was Martin Sherwin's A World Destroyed: The Atomic Bomb and The Grand Alliance (1973), which I assigned the eight times I taught the survey between 1983 and 1997. Sherwin's book successfully combines a study of the decision to deploy the atomic bombs from two intersecting perspectives: the politics of the American, British, and Soviet alliance, and the role of atomic scientists. Science is represented through discussion of the activities of a number of prominent physicists, from the origin of the Manhattan Project in the eminent theoretical physicist Leo Szilard's letter (sent under Albert Einstein's signature) to Roosevelt expressing concern at the possibility of Nazi Germany doing research that would put a nuclear weapon in Hitler's hands, to the combat use of the weapon shortly after its successful tests in the New Mexican desert on July 16, 1945. The scientists, many of them European refugees caught between their fear of Nazism and the horror that would be a nuclear war, increasingly came to fear a postwar arms race between the United States and the Soviet Union, and some called for international supervision of nuclear weapons and nuclear research. While Sherwin leaves no doubt that the atomic bombs were used to end the war, he is not indifferent to the possible assumption by Truman and his advisors of diplomatic uses of the atomic bomb in obtaining Soviet compliance with American visions of the postwar world. American leadership did not share research on the bomb with the Soviet Union during the war, and as wartime cooperation quickly evaporated after the German surrender, held tightly to the principle of American monopoly on nuclear weapons and research. Sherwin's book thus served simultaneously not only to detail the decision-making process on the use of the atomic bombs, but to open a discussion of the role of science in politics and especially in the potentially catastrophic arms race. The arms race was a fixture of the Cold War and was very much a part of my students' world when I began teaching the survey in the 1970s and when I instituted the questionnaire in the 1980s.

Because of increasing student resistance to reading long, complex texts, in 1997 I replaced the Sherwin text with J. Samuel Walker's newly published Prompt and Utter Destruction: Truman and the Use of Atomic Bombs against Japan, a short study of the political and military calculations that led to the use of the atomic bombs. In clear and concise prose, Walker methodically reaches Sherwin's conclusions: The atomic bomb was used to end the war, though it was simultaneously recognized by Truman and some of his close advisors that its existence might play a role in shaping the postwar world. Walker does not develop the scientists' position, which was certainly a loss to the 
student's understanding. But using newly opened primary sources and recently published monographs, he does deepen the narrative of American decision-making by examining more closely than Sherwin was able to do American understandings of whether Japanese leadership was ready to accept the American unconditional surrender ultimatum. He thus develops at considerable length the issues of whether the bombs were actually needed to end the war. While his conclusions are very much like Sherwin's, and like Sherwin, he discusses the terrible toll of the atomic bombs on the residents of Hiroshima and Nagasaki, Walker is less prone to step outside the frameworks utilized by the historical actors and explore or pronounce on the moral dimension of the decision. The question, "Should the atomic bomb have been deployed?" is addressed more directly, if very briefly, by Sherwin, whose answer is a circumspect "No." But the ability to deal with the question that assists in informing it, "Why were the bombs used?" did not suffer for the change of books.

\section{The Questionnaire}

Why did I develop the questionnaire? The answer, at first, was probably no more profound than that I wanted to know if the students were paying attention. After teaching the unit on the atomic bombs and the end of the war in Asia for approximately seven years, however, I had become fully aware of the significance of the pedagogical stakes involved in succeeding at this particular task. At the time I would not have used the term "civic education," to explain my purposes, but that was what I came to know I was involved in doing. I wanted to encourage students to take possession of a monumental decision that would long be a burden for Americans to explain, and simultaneously to give the students the experience of working communally, in a supportive classroom environment. I hoped to learn whether the students were open enough to this type of learning to leave the exercise with opinions that they cared to state.

From the inception of the effort to poll students in 1983 through the fourth instance of doing so in 1988, I employed a single-level questionnaire that asked students, at the close of the discussion and after they had turned in their focus papers, five questions: (1) Do you agree with the decision to develop the atomic bomb? (2) Do you agree with the decision to use the atomic bomb on Hiroshima? (3) Do you agree with the decision to use the atomic bomb on Nagasaki? (4) Do you agree with the American decision not to share nuclear research with the Soviet Union? (5) Do you agree with the decision not to seek international supervision of nuclear technology?

In 1989, I introduced a two-level questionnaire (Appendix A), which I employed through 2005, the last time I taught the survey. This form of the questionnaire attempted to gauge how the students were influenced by what they had read, discussed, and written about. Did their views change after reading Sherwin's or Walker's books? The questionnaire now asked students the same five questions on two levels: What did they think prior to their recent exposure to the issues? What did they think about them 
now, at the close of our discussion? For me, the issue was not so much in what direction students had moved. Rather, had students become engaged enough to either change their minds or confirm the position they held prior to their recent invitation to consider the issues.

A challenge was introduced at the point in the evolution of the exercise when I changed core readings, because a questionnaire designed for Sherwin's book was now employed for a different reading. While Walker dealt with the war questions, he did not deal with the future questions (refusing to share research and technology with the Soviet Union and to accept international supervision of nuclear weaponry and technology), and he did not consider the scientists' view on these issues. Nevertheless, I left those questions on the questionnaire in the belief that if, early in the discussion, the teaching assistants and I briefly explained the significance of those future questions, I could gauge whether the students at some level had an appreciation of what was at stake for the future. Considering that this subject was being offered for almost a decade in the midst of the Cold War and a great power nuclear arms race, the stakes naturally suggested themselves to students. While imperfect as a way to discover informed opinion on a complex question in international politics, the polling of the two future questions yielded some of the most revealing findings solicited from the students. These findings were especially suggestive of student engagement to the extent that for most of these students this was probably one of their first invitations, if not the first, to think about global policy issues touching on arms control and managing conflict between international adversaries.

\section{The Survey Data and Their Meaning}

I administered the questionnaire over 16 semesters. Reliable total course enrollment data exists for 11 (68\%) of those 16 semesters, and rates of participation ranged from $25 \%$ to $89 \%$ during these eleven semesters, with an average of $48 \%$. Students always had the option to not complete the anonymous questionnaire.

Students were also told that if they were undecided on any questions, they could decline to answer specific questions. Yet few respondents chose the undecided option. On the five questions, the undecideds ranged from $6 \%$ to $16 \%$, averaging $9 \%$. Those who chose this option showed a definite tendency to do so on the "future" questions ( $8 \%$ and $16 \%$ ) more than the "war" questions $(6 \%, 8 \%$, and $7 \%$ ), an explanation for which requires exploration not only on the level of the individual questions themselves, but of the exercise in general from the standpoint of the influences upon student views.

Over the sixteen semesters, the most consistent support for American decisions, an overall $69 \%$ of students surveyed, aligned with the decision to do research on and to build the atomic bomb. I believe this consensus followed the logic of war-one must never forfeit the opportunity to gain competitive advantage and to defeat an adversary. That consensus was followed only slightly by support for not sharing research and technology with the Soviet Union (averaging 66\%). The latter position fluctuated 
somewhat in time through the exacerbation of Cold War tensions in the early and late Reagan administrations and under the optimistic projections eventuating from Mikhail Gorbachev's perestroika and glasnost in the subsequent administration of George H.W. Bush. It then hardened into massive support for American decision makers within the decade after the 1991 collapse of the USSR, as if the failure of the Soviet system and the indifference of the large majority of its people to preserving it proved its general unworthiness as a partner and its inadequacy as a social and political model. Such a view was probably influenced throughout those sixteen semesters by a lecture which preceded the discussion, in which when discussing the improbability of the Grand Alliances, I spoke of the brutal, totalitarian nature of Stalin's regime. But it certainly is noteworthy that the death of the Soviet Union seemed to confirm student hostility to it rather than ease that hostility.

On other questions there was much less consensus. The use of the atomic bomb supported narrowly $(56 \%)$ in regard to Hiroshima, was rejected by a majority $(66 \%)$ in the case of Nagasaki. Over time, in contrast, students showed a lack of enthusiasm for American rejection of international supervision. Overall, only $42 \%$ approved the American stance, but it should be noted that while there were relatively few undecideds in these surveys, higher undecided totals were usually found on this one question. This could be attributable to the vagueness of the outlines of what international supervision might have looked like, let alone whether it would have been successful in light of the impasse on so many other sources of Soviet-American conflicts during the Cold War. To be sure, cooperation with the Soviet Union, in general and as loosely formulated in Sherwin's book, was in addition to a hope, an ideal and a contrary-to-fact matter. It did not happen, and students were asked to imagine the benefits of what did not happen if a dangerous, if ultimately contained, and expensive arms race had been avoided. But the assumed benefits do not seem to have been able to compete with the concreteness of the students' distrust of or hostility to the USSR, as they were informed about the Stalinist regime in class, or as it existed in current events for those who were undergraduates during 1983-1991, or in popular memory thereafter.

Data strongly suggests that the reading the students did mattered in the formulation of their views. On every question, the reading of Walker's book correlates with the hardening views toward approval of American choices and action. The reading may have eventuated in a $10 \%$ to $22 \%$ shift toward approval on the individual questions and a $15 \%$ shift across all questions. Walker's more extensive discussion of the status of the war in the Pacific and the extent of American casualties in the summer of 1945 and of the divisions among Japanese leadership on allied demands for unconditional surrender based on information not available to Sherwin may have supported for students the view that Japan was not ready to surrender, even if its situation was hopeless. Students could easily reach the conclusion that many more American lives would be lost in seeing the war to its conclusion with conventional tactics. Whether conventional warfare and control of the skies and oceans around Japan would have been sufficient to lead to a quick end of the war cannot be known. What the students did 
learn was that the atomic bombs led to a timely end of the war. Walker also makes clear that even if less lethal than the atomic bombs, conventional air bombing, including the creation of fire storms in densely populated Japanese cities, was hardly a more humane alternative. But while Walker makes a historically plausible case for the use of the second bomb, the students exercised discrimination in coming to their conclusions about the second bomb. While exactly twice as many students $(44 \%)$ reading Walker approved of the use of the second atomic bomb, the number approving remained under $50 \%$ in fifteen of those sixteen semesters, independent of which book was assigned.

As far as the "future" questions are concerned, a similar effect may be noted in regard to Sherwin's book. Sherwin's analytical creativity in seeing the decisions of political and military leadership simultaneously from the perspective of the nuclear physicists involved in the Manhattan Project might have had a similar effect on students' views of both the USSR and international supervision. Students were influenced to take seriously the implications of scientists' warnings about impending international political polarization and a dangerous nuclear arms race, and so they became more critical of (or too unsure to give an answer about) these American decisions when reading Sherwin than when reading Walker. Walker does not explicitly address either matter, to be sure, but both subjects were introduced in class discussion, and here, too, Walker's less moralized treatment might have influenced a relative hardening of attitudes. On average, after reading Sherwin, $61 \%$ approved not sharing research with the USSR and $30 \%$ approved not opting for international supervision, and $12 \%$ and $20 \%$ respectively did not choose to answer. After reading Walker, in contrast, the averages of approval of American decisions were $72 \%$ and $42 \%$ respectively, while fewer, $3 \%$ and $12 \%$, did not choose to answer.

Current events unconnected to World War II and the Cold War eventually may have been relevant to the path of student engagement. The variable hardening of student views on the war questions may not have been simply a matter of the texts alone, but of the texts read at particular individual historical moments. The Cold War was eventually not a generational experience for these students, as it had been for me and successive cohorts of undergraduates before the Soviet Union collapsed in 1991. What of the historical moments that marked these students' own generational coming of age? While the hardening of attitudes on the use of the atomic bomb at Hiroshima begins before $9 / 11$, it becomes especially pronounced thereafter in 2003, 2004, and 2005 , as did approval of the refusal to share a strategic asset with a rival and potential enemy, points to which I shall shortly return." Such observations suggest a need to

\footnotetext{
"On 9/11: as period history, Lawrence Wright, The Looming Tower: Al Qaeda and the Road to 9/11 (New York: Vintage, 2007); as memory, Alison Blais and Lynn Rasic, A Place of Remembrance, Updated Edition: Official Book of the National September 11 Memorial (Washington, DC: National Geographic, 2015); as prophecy, James Fitzgerald, The 9/11 Prophecy: Startling Evidence the End
} 
remember that past and present mingle inextricably and often unpredictably in history classes, just as they do often in the minds of historians writing about the past. Abstracting one from the other might not only be fruitless, but might represent the loss of a significant opportunity to engage students about the past and the present simultaneously, exploring the relevance of those contemporary contexts that mark their passages into public awareness. ${ }^{12}$ Bain sưggests that linking discrete subjects to "the big questions," in this case the meanings of two different significant events, makes those subjects more vividly alive, and here we have an example of the potential richness of "big questions" generated at once by the historical past and the students' own present. $^{13}$

\section{Changing Their Minds?}

Tables 1, 2, and 3 chart student opinions before and after completion of the reading, the focus paper, and the discussion section. Changes of individual minds on the five questions were common, though they sometimes involved small absolute numbers, which seem disproportionately impressive when expressed as proportions. It is significant nonetheless, as a measure of engagement with the issues, how alterable upon reflection individual student views were. Table 1 shows that of 55 total questions ( 5 per 11 semesters of the use of the dual-level questionnaire, and for which there is data), change was recorded in 53 cases $(98 \%)$. That change was more in the direction of disapproving American decisions than of approving them: On 33 of 55 questions, students changed their view in the direction of disapproval.

What determined the changes in these students' views? In looking for an answer, we again may begin by consulting the two types of questions. Table 2 suggests that students showed a greater willingness to alter their views on the "future questions" $(68 \%)$ than on the "war" questions $(54.5 \%)$. They embraced the logic of war when it came to building the bomb and deploying it twice, but when it came to thinking about the shaping of the postwar world, in which an investment of hope for the future was

"1...continued)

Times Have Begun (Medford: WND Books, 2013); and as conspiracy, Jim Marrs, The Terror

Conspiracy: Deception, 9/11, and the Loss of Liberty (Newburyport: Disinformation Books, 2006).

${ }^{12}$ The significance of the immediate generation-forming events and processes that may form the context of instruction is suggested tellingly in analysis of the late twentieth century trajectory of political tolerance, as revealed in data from surveys based on young adults; see Norman H. Nie, Jane Junn, and Kenneth Stehlik-Berry, Education and Democratic Citizenship in America (Chicago: University of Chicago Press, 1996), 159.

${ }^{13}$ Bain, What Do the Best College Teachers Do?, 37-38. 
plausible, they appeared willing in greater numbers to lean toward diplomacy to preserve the peace.

The text they were reading predictably made a difference in these decisions. In Table 2, we see that Sherwin's more explicitly critical argument yielded on every question a change of individual minds toward disapproval, while Walker's spare, less explicitly moralized text yielded mixed results, with students splitting more evenly in the incidence of change toward approval or disapproval. But students were not uniform in their response to Walker. The first two years of the use of Walker's book did not yield changes much different from those recorded when Sherwin was assigned. Beginning in 2000 and then consistently in 2001 and 2003-2005, especially on war questions, student opinions reflected a change toward approval of American actions.

It is difficult to account for this trend. Both factors internal to classroom dynamics (for example, contrarian stances toward the views stated by the teaching assistants or by me at the beginning of the discussion), or those external in the world beyond the classroom may provide answers. As Table 3, comparing 1991-2001 and 2003-2005 suggests, the trend toward changing opinions on the five questions toward approval of American decisions on the five questions begins before $9 / 11$, but certainly becomes strong thereafter during 2003-2005, years when the United States was coming to terms with the first massive attack on its territories since December 7, 1941, and, as a result, was again at war amidst growing insecurities, righteous indignation, calls for revenge, and patriotic fever.

\section{Conclusions}

The implications for history pedagogy and civic education that can be derived from this experiment in soliciting student moral engagement and student opinion documenting that engagement must remain tentative. What began somewhat casually, partly as an effort to get to know students better and get a general idea if they were paying attention to the assignment, was transformed over time into an exercise intended to help students gather their thoughts and to help me gauge the extent to which they were morally engaged and taking the issues seriously. Not long after I stopped teaching the U.S. survey, I sought to understand what the possibilities are, with the resources we possess in a large class like the survey, that instructors may stimulate engagement and learning beyond a one dimensional content-based curriculum.

In retrospect, it would have been of greater help in responding to those questions if I had thought to dig more deeply into who the students were by soliciting more social and political information about them. I might have sought to know more about their identities by asking about social and family backgrounds and their own political orientations. I might also have attempted to find ways to link their opinions about the past with their response to their own present, a matter about which I am now left to speculate. I have referenced $9 / 11$ as a generation-forming experience. Though it is a much less consequential event than $9 / 11$, I might have sought to inquire, too, about the 
possible relevance of the brief, bitter national controversy in 1994 and 1995 about the planned exhibit at the Smithsonian of the Enola Gay, the B-29 used to deliver the atomic bomb at Hiroshima. The controversy began in earnest after I had taught this unit of the course in 1994, and I did not teach the U.S. Survey again until 1996, but the Enola Gay controversy, which created an intense, public debate among historians, veterans' groups, members of Congress, and museum professionals may well have touched the minds of some students who were enrolled in my class. The presence of a father or grandfather who had fought in the Pacific may have been sufficient to animate a family discussion of the Enola Gay controversy, and hence about how the war against Japan was brought to a close. ${ }^{14}$ Finally, in the list of assignments that retrospectively I might have taken up to deepen this inquiry, as difficult as it appears to be, I might have followed the students' intellectual and civic paths into adult life, keeping in touch with at least some of them after they left the survey class and after graduation. That's the ultimate assignment, from the point of view of moral engagement, and worth consideration for anyone interested in the future in this type of pedagogy.

Ideally we want our students to go beyond simply showing up for class and appearing to pay attention. My hopes ultimately were that I might help them find a path through which they linked having to think about significant issues for a class assignment to feeling the moral responsibility to do so. Many of us possess some degree of missionary zeal for demonstrating in our teaching the relevance of history in the formation of our students' moral characters, and we judge ourselves to one extent or another by how well we are fulfilling that goal as history instructors. ${ }^{15}$ As we continue to work with students, some of whom will likely never again take another history course, we might consider various ways that we can do our own proactive work on terms that serve significant social and ethical goals.

\footnotetext{
${ }^{14}$ Edward Limenthal and Tom Engelhardt, eds., History Wars: The Enola Gay and Other Battles for the American Past (New York: Holt, 1996); Steven D. Dubin, Controversy in the American Museum from the Enola Gay to Sensation! (New York: New York University Press, 2001); Charles T. O'Reilly and William A. Rooney, Enola Gay and the Smithsonian Institution (Jefferson: McFarland, 2005); Philip Nobile, Judgment at the Smithsonian: The Uncensored Script of the Smithsonian's $50^{\text {th }}$ Anniversary Exhibit of the Enola Gay (New York: Marlowe and Company, 1995).
}

\footnotetext{
${ }^{15}$ While not speaking directly to civic learning, the U.S. Department of Education's 2012 report, Advancing Civic Learning and Engagement in Democracy: A Road Map and Call to Action, found that among university and college faculty $80 \%$ believe that teaching tolerance and respect for different beliefs is an important goal, and $75 \%$ want to encourage students to discuss controversial subjects. A decade before, among the general public and in a comprehensive survey of attitudes toward the aims of higher education, $44 \%$ saw as "absolutely essential" the goal of increasing the awareness of "the responsibilities of citizenship"; Richard J. Shavelson and Leta Huang, "Responding Responsibly to the Frenzy to Assess Learning in Higher Education," Change 35 (January/February 2003): 12. I am willing to assume that if faculty were asked to respond to this Shavelson and Huang's survey, those agreeing would be higher than $44 \%$ expressed by the general public.
} 
Table 1

Number of students changing mind before and after reading, writing paper, and discussion, 1989-2005

\begin{tabular}{|c|c|c|c|c|c|c|c|c|c|c|c|}
\hline \multirow[b]{2}{*}{ Do you approve of: } & \multicolumn{4}{|c|}{ Sherwin } & \multicolumn{7}{|c|}{ Walker } \\
\hline & $\begin{array}{c}1989 \\
N=65\end{array}$ & $\begin{array}{c}1991 \\
N=57\end{array}$ & $\begin{array}{c}1996 \\
N=34\end{array}$ & $\begin{array}{c}1997 \\
N=25\end{array}$ & $\begin{array}{c}1998 \\
N=30\end{array}$ & $\begin{array}{c}1999 \\
N=71\end{array}$ & $\begin{array}{c}2000 \\
N=93\end{array}$ & $\begin{array}{c}2001 \\
N=124\end{array}$ & $\begin{array}{l}2003 \\
N=66\end{array}$ & $\begin{array}{l}2004 \\
N=65\end{array}$ & $\begin{array}{c}2005 \\
N=40\end{array}$ \\
\hline building the bomb & $3(-5 \%)$ & $7(-12 \%)$ & $1(-3 \%)$ & $5(-20 \%)$ & $4(-14 \%)$ & $4(-6 \%)$ & $8(+9 \%)$ & $10(+8 \%)$ & $12(+18 \%)$ & $7(+11 \%)$ & $9(+23 \%)$ \\
\hline its use in Hiroshima & $9(-14 \%)$ & $5(-8 \%)$ & $2(-6 \%)$ & $3(-12 \%)$ & $5(-17 \%)$ & $4(-6 \%)$ & $5(+5 \%)$ & $19(-115 \%)$ & $15(+22 \%)$ & $14(+19 \%)$ & $12(+30 \%)$ \\
\hline its use in Nagasaki & $6(-9 \%)$ & $9(-16 \%)$ & 0 & $3(-12 \%)$ & $11(-36 \%)$ & $14(-20 \%)$ & $2(-2 \%)$ & $7(+6 \%)$ & $10(+16 \%)$ & $7(+11 \%)$ & $4(+10 \%)$ \\
\hline $\begin{array}{l}\text { not to share research } \\
\text { (USSR) }\end{array}$ & $9(-14 \%)$ & $24(-42 \%)$ & $4(-11 \%)$ & $5(-20 \%)$ & $14(-47 \%)$ & $5(-6 \%)$ & $4(-5 \%)$ & $7(+6 \%)$ & $3(-5 \%)$ & $5(+7 \%)$ & $2(-6 \%)$ \\
\hline $\begin{array}{l}\text { rejecting international } \\
\text { supervision }\end{array}$ & $2(+3 \%)$ & $9(-15 \%)$ & $3(-9 \%)$ & $3(-12 \%)$ & $7(-23 \%)$ & $4(-5 \%)$ & $2(+2 \%)$ & $1(0 \%)$ & $3(-5 \%)$ & $3(+5 \%)$ & $3(+7 \%)$ \\
\hline
\end{tabular}

$\mathrm{N}=$ number of students filling out questionnaire

$(\%)=$ percentage of students changing their opinion-plus $(+)$ means an increase in approval; minus $(-)$ means a decrease in approval 
Table 2.

Number of students changing mind: nature of issue and text used, 1989-2005

\begin{tabular}{|l|c|c|c|}
\hline & $\begin{array}{r}\text { Decline in } \\
\text { Approval }\end{array}$ & $\begin{array}{c}\text { Increase in } \\
\text { Approval }\end{array}$ & No Change \\
\hline A. "Wotal-Independent of Text & $18(55 \%)$ & $14(42 \%)$ & $1(3 \%)$ \\
B. "Future" Questions & $15(68 \%)$ & $6(27 \%)$ & $1(5 \%)$ \\
\hline II. Sherwin & $11(92 \%)$ & 0 & $1(8 \%)$ \\
A. "War" Questions & $8(100 \%)$ & 0 & 0 \\
B. "Future" Questions & $7(33 \%)$ & $14(67 \%)$ & 0 \\
\hline III. Walker & $8(57 \%)$ & $5(36 \%)$ & $1(7 \%)$ \\
\hline A. "War" Questions & & & \\
B. "Future" Questions & & & \\
\hline
\end{tabular}

Table 3.

Searching for relevant external factors: $9 / 11$ and the changes in student opinions

\begin{tabular}{|c|c|c|c|}
\hline & $\begin{array}{c}\text { Decline of } \\
\text { Approval }\end{array}$ & $\begin{array}{c}\text { Increase in } \\
\text { Approval }\end{array}$ & No Change \\
\hline $1999-2001$ & $7(47 \%)$ & $7(47 \%)$ & $1(6 \%)$ \\
\hline $2003-2005$ & $3(20 \%)$ & $12(80 \%)$ & 0 \\
\hline
\end{tabular}




\section{Appendix A. Questionnaire on the Use of Atomic Weapons in 1945}

It will take you about two minutes to complete. If you have no opinion, you may leave the answer uncircled.

The decision to build the bomb during World War II:

1. Before reading the book, I thought this was a good/bad decision.

2. After reading the book, I thought this was a good/bad decision.

The decision to use the bomb:

On Hiroshima-

1. Before reading the book, I thought this was a good/bad decision.

2. After reading the book, I thought this was a good/bad decision.

On Nagasaki-

1. Before reading the book, I thought this was a good/bad decision.

2. After reading the book, I thought this was a good/bad decision.

The decision not to share research on the bomb with the USSR during World War II:

1. Before reading the book, I thought this was a good/bad decision.

2. After reading the book, I thought this was a good/bad decision.

The decision of the American government not to favor international supervision of atomic technological development (specifically energy):

1. Before reading the book, I thought this was a good/bad decision.

2. After reading the book, I thought this was a good/bad decision.

Note: All percentage values discussed in the article, whether for sixteen or eleven semesters, are based on the numbers of questionnaires turned in, not on the total enrollment in the class. Sixteen semester data includes both the single-level and the double-level (i.e., before and after) questionnaires. Eleven semester data includes only the double-level questionnaire. 